\title{
Respiratory syncytial virus infection reduces lung inflammation and fibrosis in mice exposed to vanadium pentoxide
}

\author{
Elizabeth A Turpin ${ }^{1}$, Aurita Antao-Menezes ${ }^{1}$, Mark F Cesta ${ }^{1,2,3}$, James B Mangum', Duncan G Wallace', \\ Edilberto Bermudez ${ }^{1}$, James C Bonner ${ }^{1,3^{*}}$
}

\begin{abstract}
Background: Vanadium pentoxide $\left(\mathrm{V}_{2} \mathrm{O}_{5}\right)$ exposure is a cause of occupational bronchitis and airway fibrosis. Respiratory syncytial virus (RSV) is a ubiquitous pathogen that causes airway inflammation. It is unknown whether individuals with pre-existing respiratory viral infection are susceptible to $\mathrm{V}_{2} \mathrm{O}_{5}$-induced bronchitis. We hypothesized that respiratory viral infection will exacerbate vanadium-induced lung fibrosis.

Methods: In this study we investigated the effect of RSV pre- or post-exposure to $\mathrm{V}_{2} \mathrm{O}_{5}$ in male AKR mice. Mice were pre-exposed by intranasal aspiration to RSV or media vehicle prior to intranasal aspiration of $\mathrm{V}_{2} \mathrm{O}_{5}$ or saline vehicle at day 1 or day 7. A parallel group of mice were treated first with $\mathrm{V}_{2} \mathrm{O}_{5}$ or saline vehicle at day 1 and day 7 then post-exposed to RSV or media vehicle at day 8.

Results: $\mathrm{V}_{2} \mathrm{O}_{5}$-induced airway inflammation and fibrosis were decreased by RSV pre- or post-exposure. Real time quantitative RT-PCR showed that $\mathrm{V}_{2} \mathrm{O}_{5}$ significantly increased lung mRNAs encoding pro-fibrogenic growth factors (TGF- $\beta 1, C T G F$, PDGF-C) and collagen (Col1A2), but also increased mRNAs encoding anti-fibrogenic type I interferons (IFN- $\alpha,-\beta$ ) and IFN-inducible chemokines (CXCL9 and CXCL10). RSV pre- or post-exposure caused a significantly reduced mRNAs of pro-fibrogenic growth factors and collagen, yet reduced RNA levels of antifibrogenic interferons and CXC chemokines.

Conclusions: Collectively these data suggest that RSV infection reduces the severity of $\mathrm{V}_{2} \mathrm{O}_{5}$-induced fibrosis by suppressing growth factors and collagen genes. However, RSV suppression of $\mathrm{V}_{2} \mathrm{O}_{5}$-induced IFNs and IFN-inducible chemokines suggests that viral infection also suppresses the innate immune response that normally serves to resolve $\mathrm{V}_{2} \mathrm{O}_{5}$-induced fibrosis.
\end{abstract}

\section{Introduction}

A variety of metal oxides cause occupational lung diseases referred to as pneumoconioses. Vanadium is a transition metal commonly found in various types of ores, coals, and oil [1]. Vanadium pentoxide $\left(\mathrm{V}_{2} \mathrm{O}_{5}\right)$, the most common form of vanadium, is the primary form found in industrial exposure situations [2]. In addition, atmospheric emissions released from power plants that burn coal and oil contribute $\sim 64,000$ metric tons of vanadium into the atmosphere each year [2]. Occupational exposure to $\mathrm{V}_{2} \mathrm{O}_{5}$ dust is common in coal-

\footnotetext{
* Correspondence: james_bonner@ncsu.edu
'The Hamner Institutes for Health Sciences, Research Triangle Park, North

* Correspondence: james_bonner@ncsu.edu
${ }^{1}$ The Hamner Institutes for Health Sciences, Research Triangle Park, North Carolina 27709, USA
}

(c) 2010 Turpin et al; licensee BioMed Central Ltd. This is an Open Access article distributed under the terms of the Creative Commons

burning power plants and individuals exposed to inhaled $\mathrm{V}_{2} \mathrm{O}_{5}$-containing fly ash suffer from chronic bronchitis and reduced lung function [3,4]. The consequences of environmental exposure to lower levels of $\mathrm{V}_{2} \mathrm{O}_{5}$ on human health remain unclear, in part because air pollution particulates are a complex mixture of many organic and inorganic components, including a variety of metals [5]. However, epidemiologic evidence indicates that individuals at greatest risk for exposure to particulate air pollution are those with pre-existing respiratory diseases such as asthma and viral bronchitis [6,7].

Respiratory syncytial virus (RSV) is a ubiquitous virus that causes airway inflammation and bronchitis $[8,9]$. The virus is an enveloped negative-sense single-stranded RNA 
Paramyxovirus of the subfamily Pneumonidae [10]. Since its isolation, RSV has been identified as a leading cause of epidemic respiratory tract illness in children in the United States and worldwide [11]. Although RSV exposure in the human population occurs at a very early age, immunity is incomplete after RSV infection and secondary infections can occur throughout life. Airway epithelial cells are the primary target of RSV infection, and they respond to the infection by producing a variety of mediators involved in lung immune/inflammatory responses, such as cytokines, chemokines, and interferons [12].

Occupational bronchitis and airway fibrosis caused by $\mathrm{V}_{2} \mathrm{O}_{5}$ is recapitulated in rats or mice exposed by intratracheal instillation or pharyngeal aspiration $[13,14]$. In these studies, $\mathrm{V}_{2} \mathrm{O}_{5}$ causes airway and interstitial fibrosis that partially resolves within several weeks after exposure. Profibrogenic growth factors, including plateletderived growth factor (PDGF) and its receptor, are elevated in rats exposed to $\mathrm{V}_{2} \mathrm{O}_{5}$ [15]. The PDGF system plays a pivotal role in orchestrating myofibroblast migration and proliferation at sites of forming fibrotic lesions [16]. Moreover, tyrosine kinase inhibitors selective for PDGF or EGF receptors reduce $\mathrm{V}_{2} \mathrm{O}_{5}$-induced fibrosis in rats [17]. The partial resolution of $\mathrm{V}_{2} \mathrm{O}_{5}$-induced fibrotic lung lesions in rodents is due at least in part to the potent action of $\mathrm{V}_{2} \mathrm{O}_{5}$ as an activator of STAT-1, a transcription factor that mediates fibroblast growth arrest and apoptosis [18]. Moreover, STAT-1-deficient mice are more susceptible to pulmonary fibrosis following lung injury [19].

Studies with human cells also indicate that $\mathrm{V}_{2} \mathrm{O}_{5}$ induces both pro-fibrogenic and anti-fibrogenic factors. For example, gene expression profiling of normal human lung fibroblasts exposed to $\mathrm{V}_{2} \mathrm{O}_{5}$ in culture show increased levels of pro-fibrotic and angiogenic growth factors (PDGF, CTGF, HB-EGF, VEGF) as well as protective IFNs [20]. The production of pro-fibrogenic growth factors and antifibrogenic IFNs and chemokines is dependent on the generation of reactive oxygen species [21,22]. In general, the production of both pro-fibrogenic and anti-fibrogenic mediators by human lung cells in response to $\mathrm{V}_{2} \mathrm{O}_{5}$ is consistent with a partially resolving lung fibroproliferative response in mice or rats exposed to $\mathrm{V}_{2} \mathrm{O}_{5}$ by a single intratracheal or pharyngeal aspiration.

The hypothesis of this research is that respiratory viral infection will exacerbate vanadium-induced lung fibrosis. In contrast, we report that RSV pre- or post-exposure reduces $\mathrm{V}_{2} \mathrm{O}_{5}$-inflammation, cell proliferation, and fibrosis in male AKR mice. Moreover, RSV pre- or post-exposure significantly reduced mRNA levels of pro-fibrogenic growth factors and collagen, and yet also reduced RNA levels of anti-fibrogenic interferons and CXC chemokines. Collectively these data suggest that RSV infection reduces the severity of $\mathrm{V}_{2} \mathrm{O}_{5}$-induced fibrosis by suppressing pro-fibrogenic growth factors and collagen genes. However, RSV suppression of $\mathrm{V}_{2} \mathrm{O}_{5}$-induced IFNs and IFN-inducible chemokines also suggests that viral infection has a negative effect on the immune response triggered by $\mathrm{V}_{2} \mathrm{O}_{5}$ exposure. These results have potentially important ramifications, since a wide variety of metal oxides cause occupational lung diseases and RSV infection is commonplace.

\section{Materials and methods Animals}

Six-week old male pathogen-free CDF AKR mice were purchased from The Jackson Laboratory (Bar Harbor, ME) and housed in an Association for Assessment and Accreditation of Laboratory Animal Care (AAALAC)-accredited facility that was humidity and temperature controlled. AKR mice were tested as they are susceptible to both RSV and metal induced bronchitis [23]. Mice were housed in microisolator cages on Alpha-dri cellulose bedding and supplied water and cereal-based diet NIH07 (Zeiger Brothers., Gardners, PA) ad libitum. The animal studies were approved by The Hamner Institutes for Health Sciences Institutional Animal Care and Use Committee.

\section{Experimental design}

Animals were randomly assigned to treatment groups (seven mice per group) and acclimated for two weeks. Treatment groups included a media control (media collected from non-inoculated Vero cells), $\mathrm{V}_{2} \mathrm{O}_{5}$, RSV pretreatment, RSV post-treatment, RSV pretreatment $+\mathrm{V}_{2} \mathrm{O}_{5}$, or RSV post-treatment $+\mathrm{V}_{2} \mathrm{O}_{5}$ (Fig. 1). RSV strain A2 (a kind gift from Dr. Ralph Tripp, University of Georgia, Athens) was propagated in Vero cells and concentrated using Amicon Ultra filters (Millipore Corporation, Bedford, MA). RSV was diluted to $6 \times 10^{5}$ PFU in a $100 \mu \mathrm{l}$ dose and inoculated intranasally into both nares on days -1 and 8 under light isoflurane anesthesia. A pilot group of mice were exposed to RSV and lung harvested at day 4 to determine the presence of RSV in whole lung tissue by ELISA as described below. $\mathrm{V}_{2} \mathrm{O}_{5}$ (Sigma-Aldrich Chemical, St. Louis, MO) was suspended in PBS and sonicated for 30 minutes. Mice were given intranasal inoculation of $50 \mu \mathrm{l}$ of $\mathrm{V}_{2} \mathrm{O}_{5}$ $(4 \mathrm{mg} / \mathrm{kg}$ ) or PBS into both nares on days 0 and 7 under light isoflurane anesthesia. Preliminary studies demonstrated that intranasal administration of either RSV or $\mathrm{V}_{2} \mathrm{O}_{5}$ resulted in even distribution in all lung lobes (data not shown). Negative control animals were treated with PBS. Animals were euthanized at 21 days following initial particle exposure.

\section{Necropsy and preparation of lung tissues}

One hour prior to euthanasia, mice received a single intraperitoneal injection of $50 \mathrm{mg} / \mathrm{kg}$ body weight of 




Figure 1 Experimental Design for exposing adult male AKR mice to RSV and $\mathbf{V}_{\mathbf{2}} \mathbf{O}_{\mathbf{5}}$. A pilot group of mice received an intranasal exposure to RSV or media vehicle alone to test for infection in the lungs at day 4. All other histopathology and gene expression endpoints listed were assessed at 21 days following intranasal exposure to RSV $\left(6 \times 10^{5} \mathrm{PFU}\right)$ and/or $\mathrm{V}_{2} \mathrm{O}_{5}(4 \mathrm{mg} / \mathrm{kg})$ as described in Methods.

bromodeoxyuridine (BrdU; Sigma-Aldrich). The lungs were lavaged with PBS as described below, the right lung lobes were snap-frozen in liquid nitrogen and stored at $-80^{\circ} \mathrm{C}$ and used for RNA isolation and collagen assay as described below. The left lungs were pressureinfused intratracheally at $20 \mathrm{~cm} \mathrm{H}_{2} \mathrm{O}$ with $10 \%$ neutralbuffered formalin. The same lungs were lavaged and sampled for histopathology, collagen, quantitative PCR, and ELISA assays to allow for direct comparison of assay results. Lungs were fixed for approximately 48 hours and then changed into $70 \%$ ethanol. Three cross-sectional portions of the left lung were embedded in paraffin, sectioned at $5 \mu \mathrm{m}$, and stained with Masson's trichrome, hematoxylin and eosin, or immunostained for BrdU as described below.

\section{Bronchoalveolar lavage}

Mice were euthanized by pentobartital overdose and lungs were lavaged five times with 1-ml volumes of PBS. Bronchoalveolar lavage fluid (BALF) collected from the first two recovered lavages were pooled and placed on ice. The subsequent three lavages were pooled and placed on ice. BAL cells collected by centrifugation were resuspended in culture medium and enumerated using an automated cell counter (Model ZM, Coulter, Marietta, GA). Cytospins were prepared with $10^{5}$ cells per slide. Cell differential counts, performed on HEMA-3 (Fisher Scientific, Pittsburgh, PA) stained cytocentrifuge slide preparations, were based on a total number of 350 cells. Total protein and lactate dehydrogenase (LDH) in cellfree BALF from the first two pooled lavages were analyzed spectrophotometrically using a COBAS FARA II (Roche Diagnostic Systems Inc., Montclair, NJ).

\section{Lung histopathology and pathology scoring}

The lungs from the 21 day time point were scored for fibrosis according to our previously reported method
[24]. The left lung lobe was formalin-fixed, embedded in paraffin and cut in $5-\mu \mathrm{m}$ sections. The lungs were scored for the amount of collagen present (based on Masson's trichrome-stained sections), the thickness of the alveolar walls, and the number of fibroblast-like cells associated with the lesions. Sections were scored blindly on a relative scale where zero represented the levels of these parameters in the PBS control group, 1 representing minimal fibrosis, 2 representing mild fibrosis, 3 representing moderate fibrosis, 4 representing marked fibrosis, and 5 representing severe fibrosis.

\section{Bromodeoxyuridine (BrdU) immunohistochemistry and Cell Proliferation}

Cell labeling indices were determined in the bronchiolar/ alveolar region and in the bronchus-associated lymphoid tissue for each animal, and the mean labeling index was calculated for each group of eight animals. The BALT was examined as it is believed to facilitate primary immune response to respiratory infection and would serve as a marker for inflammation in the lung [25].

\section{RSV ELISA}

Lung samples from mice were analyzed on an antigen capture ELISA modified from previously described protocols [26,27]. A goat anti-RSV polycolonal antibody (0601, ViroStat, Portland, ME) was diluted 1:500 in Tris-buffered saline (TBS), $100 \mu \mathrm{l}$ added per well and incubated overnight at $4^{\circ} \mathrm{C}$. Plates were washed with TBS+ $0.05 \%$ Tween 20 (TBST) and blocked with $200 \mu \mathrm{l}$ of TBST with $1 \%$ BSA for $1 \mathrm{~h}$ at room temperature. Plates were washed three times to remove blocking buffer. Lung homogenates were prepared by homogenizing the right accessory lung lobe in $500 \mathrm{ml}$ of PBS for $5 \mathrm{~s}$ with a tissue homogenizer. Lung homogenates were diluted 1:5 and $100 \mu \mathrm{l}$ added per well in duplicate and incubated overnight at $4^{\circ} \mathrm{C}$. After washing, $100 \mu \mathrm{l}$ of a 
biotin conjugated anti-RSV polyclonal antibody (0607, ViroStat) diluted 1:500 in TBST with 1\% BSA was added and incubated for $1 \mathrm{hr}$ at room temperature. Plates were then washed three times and $100 \mu \mathrm{l}$ of ExtrAvidin-peroxidase (E2886, Sigma-Aldrich) diluted 1:1000 in TBST with $1 \%$ BSA. Plates were washed three times and detected with 3,3',5,5'-Tetramethylbenzidine (TMB, T5524, Sigma-Aldrich). After $30 \mathrm{~min}$ incubation, the reaction was stopped with $0.5 \mathrm{~N} \mathrm{H}_{2} \mathrm{SO}_{4}$. The values are expressed as the OD observed at $450 \mathrm{~nm}$.

\section{Collagen Assay}

The right cranial lobe of each mouse lung was suspended in PBS at 50-100 $\mathrm{mg}$ tissue per $\mathrm{ml}$ and homogenized for $10 \mathrm{~s}$ with a Tissuemiser homogenizer (Fisher Scientific). Cellular debris was pelleted by centrifugation and the supernatant analyzed for total protein with the BCA Assay Kit (Pierce/ThermoFisher Scientific, Rockford, IL) according to the manufacturer's instructions. The Sircol ${ }^{\text {Tut }}$ Soluble Collagen Assay kit (Biocolor Ltd., Northern Ireland) was used to extract collagen from duplicate samples by using $100 \mu \mathrm{l}$ of supernatant mixed with acetic acid and $500 \mu \mathrm{l}$ of Sircol Dye Reagent according to the manufacturer's instructions. Similarly prepared collagen standards $(10-50 \mu \mathrm{g})$ were run in parallel. Collagen was pelleted by centrifugation; pellets were washed twice with denatured alcohol and dried prior to suspension in Alkali reagent. Absorbance at 540 nm was read on a Multiskan EX microplate spectrophotometer (ThermoFisher Scientific) microplate reader with Ascent software. Data were expressed as $\mu \mathrm{g}$ of soluble collagen per mg of total protein.

\section{Taqman quantitative RT-PCR}

Total RNA from the right anterior lung was isolated using TRIZOL reagent (Invitrogen, Carlsbad, CA), followed by RNA cleanup performed using RNeasy Midi spin columns (Qiagen, Valencia, CA). One microgram of total RNA was reverse transcribed at $48^{\circ} \mathrm{C}$ for 30 minutes using Moloney murine leukemia virus reverse transcriptase (Eurogentec, San Diego, CA) in 1× RT buffer, $5 \mathrm{mM}$ $\mathrm{MgCl}_{2}, 500 \mu \mathrm{M}$ of each dNTP, $2.5 \mu \mathrm{M}$ of random nonamers, and $0.4 \mathrm{U} / \mu \mathrm{L}$ RNase inhibitor in a volume of 100 $\mu \mathrm{l}$. Twenty nanograms of the RT product was amplified using Taqman Gene Expression Assays specific for platelet-derived growth factor receptor alpha (PDGFR $\alpha$ ), PDGF-A, PDGF-C, transforming growth factor beta-1 (TGF- $\beta 1$ ), connective tissue growth factor (CTGF), type I procollagen (COL1A2), vascular endothelial growth factor (VEGF) and 18S on the Applied Biosystems 7900 Prism $^{\circ}$ Sequence Detection System (Applied Biosytems, Foster City, CA). The PCR conditions and data analysis were performed according to the manufacturer's protocol described in User bulletin no.2, Applied Biosystems
Prism 7700 Sequence Detection System. Gene expression was measured by the quantitation of cDNA converted from mRNA corresponding to the target genes relative to the vehicle-treated control groups and normalized to eukaryotic $18 \mathrm{~S}$ reference endogenous control. Relative quantitation values $\left(2^{-\Delta \Delta C T}\right)$ were expressed as foldchange over controls.

\section{Data and statistical analysis}

All graphs were constructed and statistical analysis performed using GraphPad Prism ${ }^{\circ}$ software v. 5.00 (GraphPad Software, Inc., San Diego, CA). A one-way ANOVA with a post-hoc Tukey test was used to identify significant differences among treatment groups.

\section{Results}

We first sought to determine whether RSV would infect the lungs of $A K R$ mice after a single intranasal inoculation in the absence of any $\mathrm{V}_{2} \mathrm{O}_{5}$ exposure. Using an RSVspecific ELISA, we found that the intranasal delivery of RSV caused infection in the lungs of mice after 4 days (Fig. 2). An optical density (O.D.) value of 0.2 represented no virus. RSV infection was accompanied by a transient inflammatory response in the airways of AKR mice observed at 4 days (data not shown). Collectively these data show that the intranasal inoculation of RSV resulted in viable, replicating RSV within the lungs of AKR mice. Lung samples were also analyzed at day 21 in all mice and no RSV was detected (data not shown) as would be expected. In addition, the effect of $\mathrm{V}_{2} \mathrm{O}_{5}$ on RSV replication was evaluated in vitro using cultured human lung epithelial $\mathrm{H} 292$ cells. In these in vitro experiments, $\mathrm{V}_{2} \mathrm{O}_{5}$



Figure 2 Detection of RSV in the lungs of male AKR mice 4 days after a single intranasal aspiration of virus-containing media or media vehicle alone. The presence of RSV in the lungs was measured by ELISA as described in Methods. Data were analyzed by Student's t-test. ${ }^{* *} P<0.001$ compared to Media. 
treatment had no effects on virus replication with pre or post treatment (data not shown).

Airway fibrosis, increased airway wall thickness due to increased collagen and/or fibroblasts around the airways, as well as interstitial fibrotic lesions within the lung parenchyma, increased septal thickening due to collagen and/or fibroblasts in the alveolar region, was significantly increased by 21 days following a single intranasal exposure to $\mathrm{V}_{2} \mathrm{O}_{5}$ (Fig. 3A). The airway fibrotic response to $\mathrm{V}_{2} \mathrm{O}_{5}$ exposure in AKR mice was qualitatively less severe in mice that received either pre- or post-RSV exposure, whereas RSV exposure alone did not appear different from media control exposed control lung tissue at 21 days (Fig. 3A). In a blinded pathology evaluation of the lung sections, the $\mathrm{V}_{2} \mathrm{O}_{5}$-induced inflammation score was significantly reduced by RSV post-exposure, whereas RSV pre-exposure had no effect on the $\mathrm{V}_{2} \mathrm{O}_{5^{-}}$ induced inflammation score (Fig. 3B). The lungs of the $\mathrm{V}_{2} \mathrm{O}_{5}$ treated mice had increased inflammation composed of increased total numbers of cells as well as increased numbers of neutrophils and lymphocytes. In addition, $\mathrm{V}_{2} \mathrm{O}_{5}$ significantly increased total lung collagen levels as measured by Sircol assay, but not when mice were pre- or post-exposed to RSV (Fig. 3C). $\mathrm{V}_{2} \mathrm{O}_{5}$ treatment increased the total BAL numbers when give alone or with RSV post-exposure, while RSV pre-exposure and RSV pre-exposure $+\mathrm{V}_{2} \mathrm{O}_{5}$ levels were similar to controls (Fig 4). $\mathrm{V}_{2} \mathrm{O}_{5}$ increased the numbers of neutrophils and lymphocytes in BAL fluid at 21 days post-exposure mirroring what was observed in lesion scoring of lungs (Fig. 4). RSV exposure alone also increased the numbers of BAL neutrophils and lymphocytes. However, RSV

A)
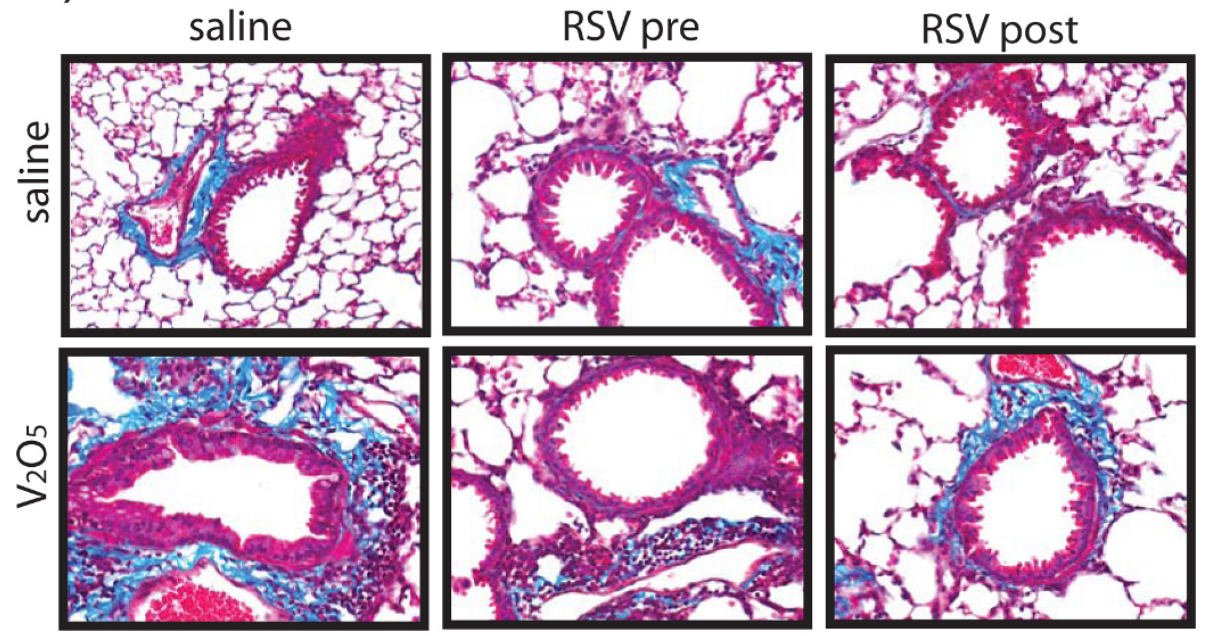

B)



C)

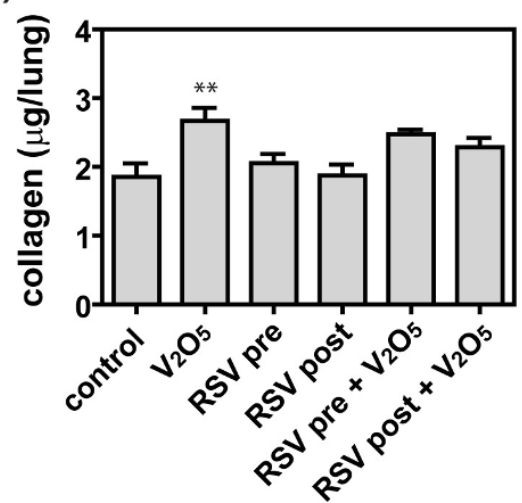

Figure $\mathbf{3}$ Lung histopathology at $\mathbf{2 1}$ days in male AKR mice treated with RSV and/or $\mathbf{V}_{\mathbf{2}} \mathrm{O}_{\mathbf{5}}$. (A) Representative airway pathology in mice exposed to $\mathrm{V}_{2} \mathrm{O}_{5}$ with or without RSV pre- or post-exposure. Lung sections were stained with Masson's trichrome to show collagen (blue staining). (B) Inflammation scores were determined in a blinded manner as described in Methods. Data were analyzed by One-way ANOVA followed by Tukey's test. ${ }^{* *} \mathrm{P}<0.01$ or ${ }^{* *} \mathrm{P}<0.001$ compared to $\mathrm{V}_{2} \mathrm{O}_{5}$. (C) Lung collagen was measured by Sircol ${ }^{\mathrm{TM}}$ assay as described in Methods. Data were analyzed by One-way ANOVA followed by Tukey's test. ${ }^{*} \mathrm{P}<0.01$ compared to Control. 



Figure 4 Cell differential counts in bronchoavleolar lavage (BAL) fluid at 21 days after exposure to $\mathrm{V}_{2} \mathrm{O}_{5}$ in the absence or presence of RSV pre- or post-exposure showing total numbers of BAL cells recovered by lavage (A) the relative percentages of (B) macrophages, (C) neutrophils, and (D) lymphocytes. Data were analyzed by One-way ANOVA followed by Tukey's multiple comparison test. ${ }^{*} P<0.05$, ${ }^{* * P}<0.01$, or ${ }^{* * *} \mathrm{P}<0.001$ compared to Control.

pre- or post-exposure reduced the $\mathrm{V}_{2} \mathrm{O}_{5}$-induced increase in these inflammatory cells by $\sim 50 \%$ (Fig. 4).

Cell proliferation, as assessed by BrdU-positive nuclei, was significantly increased around airways and in the lung parenchyma of mice 21 days after $\mathrm{V}_{2} \mathrm{O}_{5}$ exposure (Fig. 5). BrdU-positive epithelial and sub-epithelial mesenchymal cells were observed in the airways and lung parenchyma of mice exposed to RSV and/or $\mathrm{V}_{2} \mathrm{O}_{5}$ (data not shown). BrdU labeling was $>1 \%$ in the lungs of control animals. RSV exposure alone also caused an increase in cell proliferation, although the number of BrdU-positive cells were one-third to half of that observed for $\mathrm{V}_{2} \mathrm{O}_{5}$ alone. RSV pre- or post-exposure did not significantly change the cell proliferation index in either airways or lung parenchyma (Fig. 5).

We next sought to determine the effect of RSV on the mRNA levels of growth factors and collagen induced by $\mathrm{V}_{2} \mathrm{O}_{5}$. The mRNAs encoding several pro-fibrogenic growth factors (TGF- $\beta 1, \mathrm{CTGF}$, and PDGF-C) were significantly increased by $\mathrm{V}_{2} \mathrm{O}_{5}$ exposure in whole lung tissue at 21 days post-exposure (Fig. 6). RSV exposure alone did not significantly increase the mRNA levels of any of these three growth factors nor was the collagen (Col1A2) mRNA level increased by RSV alone. However, RSV pre- or post-exposure completely inhibited $\mathrm{V}_{2} \mathrm{O}_{5}$ induced growth factor and collagen mRNA levels at 21 days (Fig. 6).

Since IFNs and IFN-inducible CXC chemokines have been suggested to play a role in the resolution of $\mathrm{V}_{2} \mathrm{O}_{5^{-}}$ induced fibrogenesis, we also assessed the effect of RSV on mRNA levels encoding type I IFNs (IFN- $\alpha$ and IFN- $\beta$ ) and downstream chemokines CXCL9 (Mig) and CXCL10 (IP10). The mRNAs encoding (IFN- $\alpha$, IFN- $\beta$, CXCL9, and CXCL10 were significantly increased by $\mathrm{V}_{2} \mathrm{O}_{5}$ exposure in whole lung tissue at 21 days post-exposure (Fig. 7). RSV exposure alone marginally increased mRNA levels of IFN- $\alpha$ and IFN- $\beta$, but did not increase CXCL9 or CXCL10 mRNAs at 21 days. RSV pre- or post-exposure completely blocked $\mathrm{V}_{2} \mathrm{O}_{5}$-induced mRNA levels of IFN- $\alpha$, IFN- $\beta$, CXCL9, and CXCL10 (Fig. 7). 



Figure 5 Cell proliferation in the lungs of male AKR mice at 21 days after exposure to $\mathrm{V}_{2} \mathrm{O}_{5}$ in the absence or presence of RSV pre- or post-exposure. Bromodeoxyuridine (BrdU)-positive cells were quantified in (A) lung parenchyma and (B) airways as described in Methods. Data were analyzed by One-way ANOVA followed by Tukey's multiple comparison test. ${ }^{*} \mathrm{P}<0.05$ compared to Control.

\section{Discussion}

RSV is known to exacerbate airway diseases such as cystic fibrosis and asthma [28-30]. Moreover, the toxicity of air pollutant particles is generally thought to be increased by viral infections, and conversely, some air pollutant particles increase viral infections [31,32]. Nevertheless, the effect of respiratory viral infection on the pathogenesis of occupational lung diseases caused by the inhalation of metals has not been previously investigated to our knowledge. We hypothesized that RSV infection would increase airway fibrosis and remodeling caused by $\mathrm{V}_{2} \mathrm{O}_{5}$, a transition metal that causes occupational bronchitis in individuals working in coal and oil-burning power plants. Surprisingly, we found that RSV infection before $\mathrm{V}_{2} \mathrm{O}_{5}$ exposure reduced the lung inflammation score, whereas RSV infection after $\mathrm{V}_{2} \mathrm{O}_{5}$ significantly reduced lung inflammation as compared to metal exposure alone. RSV pre- or post-exposure significantly reduced $\mathrm{V}_{2} \mathrm{O}_{5}$-induced increases in neutrophil and lymphocyte infiltration into the lung. Furthermore, $\mathrm{V}_{2} \mathrm{O}_{5}$ exposure alone significantly increased lung collagen, whereas we observed no significant increase in lung collagen in mice that received RSV before or after $\mathrm{V}_{2} \mathrm{O}_{5}$.

The reduction in $\mathrm{V}_{2} \mathrm{O}_{5}$-induced fibrosis by RSV infection was accompanied by a marked reduction in mRNAs encoding pro-fibrogenic growth factors and collagen. Exposure to $\mathrm{V}_{2} \mathrm{O}_{5}$ in the absence of RSV increased TGF- $\beta 1$ and collagen mRNA levels severalfold after 21 days of exposure. TGF- $\beta 1$ has long been regarded as the most potent stimulator of collagen synthesis during lung fibrosis [33]. RSV exposure alone caused no induction of TGF- $\beta 1$ or collagen mRNAs at 21 days and completely suppressed $\mathrm{V}_{2} \mathrm{O}_{5}$ induction of
TGF- $\beta 1$ and collagen mRNAs. CTGF and PDGF-C, which also mediate collagen deposition and/or fibroblast survival $[16,34]$, were induced by $\mathrm{V}_{2} \mathrm{O}_{5}$ several-fold and induction was blocked by RSV at 21 days. Therefore, the overall pattern of RSV effect on $\mathrm{V}_{2} \mathrm{O}_{5}$-stimulated responses was to block pro-fibrogenic signaling. A limitation of our analysis was that we assayed mRNA levels at 21 days post $-\mathrm{V}_{2} \mathrm{O}_{5}$ exposure. It is possible that RSV caused changes in mRNA levels encoding these profibrogenic mediators at earlier time points and returned to baseline levels of expression by 21 days.

The effect of RSV pre-exposure or post-exposure was previously studied in combination with carbon black (CB) ultrafine particles using BALB/C mice $[26,35]$. In experiments where mice were first exposed to $C B$ and then RSV, viral titers in RSV + CB mice were lower than RSV alone on days 2-4 of infection, and yet by day 7 of expsoure neutrophil numbers, proinflammatory cytokine mRNA expression, and protein levels of TNF-alpha and the Th2 cytokine interleukin (IL)-13 were increased in the lungs of RSV + CB mice, indicating an exacerbation of infection [26]. These data indicated that pre-exposure to ultrafine particles induces an allergic (Th2) immune response rather than an IFN- $\gamma$-mediated (Th1) response production necessary for microbial defense. In a second study by the same investigators, mice were intratracheally instilled with CB particles after 3 days of RSV infection [35]. Neutrophil and lymphocyte numbers were higher on days 4 and 14 of infection in CB-exposed, RSVinfected mice. CB exposure also enhanced RSV-induced airway hyperresponsiveness to methacholine, bronchoalveolar lavage (BAL) total protein, and virus-associated chemokines monocyte chemoattractant protein (MCP-1), macrophage inflammatory protein (MIP-1 alpha), and 



Figure 6 Quantification of mRNAs encoding growth factors (TGF- $\beta$ 1, CTGF, PDGF-C) and collagen (Col1A2). The mRNA levels for each growth factor or collagen was measured by Taqman quantitative real-time RT-PCR. Data were analyzed by One-way ANOVA followed by Tukey's test. Comparisons were $\mathrm{V}_{2} \mathrm{O}_{5}$ versus Control or $\mathrm{V}_{2} \mathrm{O}_{5}$ versus other treatments as indicated. ${ }^{*} \mathrm{P}<0.05$, ${ }^{* *} \mathrm{P}<0.01$, ${ }^{* *} \mathrm{P}<0.001$.

regulated upon activation, normal $\mathrm{T}$ cell expressed and secreted (RANTES). These data demonstrated a synergistic effect of ultrafine CB particles on RSV infection, and suggest a potential mechanism for increased respiratory infections in human populations after PM exposure. In contrast to the studies by Lambert and coworkers described above, our data show that either pre- or postexposure to RSV reduced $\mathrm{V}_{2} \mathrm{O}_{5}$-induced lymphocyte and neutrophil influx into the lung, decreased pro-fibrogenic growth factor and collagen mRNAs, and reduced inflammation and fibrosis.

As mentioned above, the toxic effects of air pollution particles is generally thought to be increased by viral infections [31]. For example, diesel exhaust particles enhance influenza virus infection in human airway epithelial cells and the enhanced susceptibility to diesel exhaust by influenza infection is associated with decreased surfactant protein expression [32,36]. However, the interactive effects between virus and pollutant particle could largely depend on the type of virus and the composition of the pollutant particle in question. Air pollution particles are a complex mixture of organic (e.g., carbon, polycyclic aromatic hydrocarbons) and inorganic constituents (e.g., transition metals) [5]. Vanadium-containing air pollution particles are released at the highest levels in oil-burning power plants that 




release residual oil fly ash into the atmosphere [6]. These vanadium-containing fly ash particles then contribute to urban ambient particulates (UAP). Our data in mice exposed to pure $\mathrm{V}_{2} \mathrm{O}_{5}$ suggest that pre-exposure to RSV infection would not increase the risk to vanadiumcontaining UAP. However, it would be important to determine whether RSV would exacerbate the effects of vanadium-containing UAP in the lung or whether other types of viral infections (e.g., influenza) would increase lung inflammation or fibrosis caused by vanadium-containing UAP or pure $\mathrm{V}_{2} \mathrm{O}_{5}$.

Viral infection has been implicated in the pathogenesis of idiopathic pulmonary fibrosis (IPF). While little is known about the mechanisms of IPF, the disease is likely multi-factorial, and viruses have been implicated as co-factors (either as initiating or exacerbating agents) of fibrotic lung disease [37]. Specifically, experimental data suggests a link between hepatitis $C$ virus, adenovirus, human cytomegalovirus and the Epstein-Barr gammaherpesvirus, in IPF [38]. Therefore, despite the findings of our study, viral infections should be considered as potential initiators or exacerbating agents in at least some cases of IPF and possibly other types of occupational and environmental lung diseases that involve fibrotic responses.

The mechanism(s) through which V2O5 exerts a fibrogenic effect in the lungs of mice is likely complex and further confounded by RSV exposure. While $\mathrm{V}_{2} \mathrm{O}_{5}$ 
clearly has pro-fibrogenic activity in the lungs of mice and increased growth factor levels that mediate fibrosis, $\mathrm{V}_{2} \mathrm{O}_{5}$ also increased type I IFNs (IFN- $\alpha$ and IFN- $\beta$ ) along with IFN-inducible chemokines CXCL10 and CXCL9. Furthermore, we observed that RSV blocked $\mathrm{V}_{2} \mathrm{O}_{5}$-induced increases in IFN and CXC chemokine mRNAs. IFNs could be protective against fibrosis by causing growth arrest and apoptosis of fibroblasts, and CXCL10 has been reported to have angiostatic properties [39]. We have also reported that $\mathrm{V}_{2} \mathrm{O}_{5}$ is a potent activator of type I IFN production by lung fibroblasts that leads to STAT-1 activation and proposed this mechanism in the resolution $\mathrm{V}_{2} \mathrm{O}_{5}$-induced fibrosis [22] The RSV surface attachment protein (G protein) has been shown to inhibit Toll-like receptor (TLR) 3/4mediated IFN- $\beta$ induction [40] a feature that may facilitate virus replication. In the present study, we found that RSV reduces $\mathrm{V}_{2} \mathrm{O}_{5}$-induced mRNA levels of type I IFNs, CXCL9 and CXCL10. Therefore, while RSV reduces $\mathrm{V}_{2} \mathrm{O}_{5}$-induced fibrosis in AKR mice, this effect is limited by the action of RSV in also reducing potentially protective IFNs and chemokines.

Finally, it may be noteworthy that certain metals, including vanadium, possess broad spectrum anti-viral activity that includes inhibition of RSV replication [41]. We did not specifically address the issue of viral replication in the lungs of mice exposed to $\mathrm{V}_{2} \mathrm{O}_{5}$ in the present study. An important focus of future study will be to determine if RSV or other viruses (e.g., influenza) are inhibited by $\mathrm{V}_{2} \mathrm{O}_{5}$ or vanadium-containing air pollutant particles.

\section{Conclusions}

The intranasal inoculation of mice with RSV clearly did not exacerbate $\mathrm{V}_{2} \mathrm{O}_{5}$-induced pulmonary inflammation and fibrosis, but rather reduced these pathologic endpoints and reduced $\mathrm{V}_{2} \mathrm{O}_{5}$-induced neutrophil and lymphocyte infiltration into the lungs. Moreover, RSV pre-or post-exposure significantly reduced mRNA levels of pro-fibrogenic growth factors and collagen, and yet also reduced RNA levels of anti-fibrogenic interferons and CXC chemokines. Collectively these data suggest that RSV infection reduces the severity of $\mathrm{V}_{2} \mathrm{O}_{5}$-induced fibrosis by suppressing pro-fibrogenic growth factors and collagen genes. However, RSV suppression of $\mathrm{V}_{2} \mathrm{O}_{5}-$ induced IFNs and IFN-inducible chemokines also suggests that viral infection has a negative effect on the immune response triggered by $\mathrm{V}_{2} \mathrm{O}_{5}$ exposure. Our findings in mice suggest that RSV infection does not increase the risk of occupational bronchitis caused by vanadium exposure. Further studies should address whether occupational lung disease caused by the inhalation of metals other than vanadium are modulated in a positive or negative way by RSV infection.

\section{List of Abbreviations}

RSV: respiratory syncytial virus; $\mathrm{V}_{2} \mathrm{O}_{5}$ : vanadium pentoxide; PDGF: platelet-derived growth factor; TGF: transforming growth factor; CTGF: connective tissue growth factor; IFN: interferon; CXCL: CXC-motif ligand chemokine; STAT-1: signal transducer and activator of transcription.

\section{Acknowledgements}

The authors gratefully acknowledge Vickie Wong, David Weil, and Deloris Williams at The Hamner Institutes for Health Sciences for outstanding technical expertise. We thank Dr. Mel Andersen at The Hamner Institutes for helpful comments during the preparation of this manuscript. This work was funded by National Institutes of Health (NIH R21-ES015801-01), The LongRange Research Initiative (LRRI) of the American Chemistry Council (ACC) provided to The Hamner Institutes for Health Sciences, and The Intramural Program of the National Institutes of Health, National Institute of Environmental Health Sciences.

\section{Author details}

${ }^{1}$ The Hamner Institutes for Health Sciences, Research Triangle Park, North Carolina 27709, USA. ${ }^{2}$ Laboratory of Cellular and Molecular Pathology, National Institute of Environmental Health Sciences, Research Triangle Park, North Carolina, 27709, USA. ${ }^{3}$ Department of Environmental and Molecular Toxicology, North Carolina State University, Raleigh, North Carolina 27695, USA.

\section{Authors' contributions}

EAT and JCB designed the experiments, performed the data analysis, and drafted the manuscript. EAT, AAM, JBM, DGW, and EB performed mouse necropsy, BAL, RNA isolation and Taqman quantitative real-time RT-PCR. MFC performed histopathology analysis and scoring. All authors read and approved the final manuscript.

\section{Competing interests}

The authors declare that they have no competing interests.

Received: 23 July 2009

Accepted: 22 February 2010 Published: 22 February 2010

\section{References}

1. Zenz C, Ed: Occupational Medicine. Mosby, St. Louis, MO, 3 1994, 584-594.

2. World Health Organization (WHO): Vanadium pentoxide and other inorganic vanadium compounds. Concise International Chemical Assessment Documents, Document 292001.

3. Woodin MA, Liu Y, Hauser R, Smith TJ, Christiani DC: Pulmonary function in workers exposed to low levels of fuel-oil ash. $J$ Occup Environ Med 1999, 41:973-980.

4. Woodin MA, Liu Y, Neuberg D, Hauser R, Smith TJ, Christiani DC: Acute respiratory symptoms in workers exposed to vanadium-rich fuel-oil ash. Am J Indust Med 2000, 37:353-363.

5. Bonner JC: Lung fibrotic responses to particle exposure. Toxicol Pathol 2007, 35(1):148-153.

6. Ghio AJ, Silbajoris R, Carson JL, Samet JM: Biologic effects of oil fly ash. Environ Health Perspect 2002, 1:89-94.

7. Gavett SH, Koren HS: The role of particulate matter in exacerbation of atopic asthma. Int Arch Allergy Immunol 2001, 124:109-12.

8. Tripp RA, Oshansky C, Alvarez R: Cytokines and respiratory syncytial virus infection. Proc Am Thorac Soc 2005, 2:147-149.

9. Tripp RA: Pathogenesis of respiratory syncytial virus infection. Viral Immunol 2004, 17:165-81.

10. Harris J, Werling D: Binding and entry of respiratory syncytial virus into host cells and initiation of the innate immune response. Cell Microbiol 2003, 5(10):671-80.

11. Staat MA: Respiratory syncytial virus infections in children. Semin Respir Infect 2002, 17:15-20 
12. Haeberle HA, Kuziel WA, Dieterich HJ, Casola A, Gatalica Z, Garofalo RP: Inducible expression of inflammatory chemokines in respiratory syncytial virus-infected mice: role of MIP-1alpha in lung pathology. J Virol 2001, 75(2):878-90

13. Bonner JC, Rice AB, Moomaw CR, Morgan DL: Airway fibrosis in rats induced by vanadium pentoxide. Am J Physiol 2000, 278:L209-L216.

14. Bonner JC, Rice AB, Ingram JL, Moomaw CR, Nyska A, Bradbury A Sessoms AR, Chulada PC, Morgan DL, Zeldin DC, Langenbach R: Susceptibility of cyclooxygenase (COX)-2 deficient mice to pulmonary fibrosis. Am J Pathol 2002, 161:459-470.

15. Bonner JC, Lindroos PM, Rice AB, Moomaw CR, Morgan DL: Induction of PDGF receptor-alpha in rat myofibroblasts during pulmonary fibrogenesis in vivo. Am J Physiol 1998, 274:L72-80.

16. Bonner JC: Regulation of PDGF and its receptors in fibrotic diseases. Cytokine Growth Factor Rev 2004, 15:255-273.

17. Rice $A B$, Moomaw CR, Morgan DL, Bonner JC: Specific inhibitors of platelet-derived growth factor or epidermal growth factor receptor tyrosine kinase reduce pulmonary fibrosis in rats. Am J Pathol 1999, 155(1):213-21.

18. Wang $Y Z$, Ingram JL, Walters $D M$, Rice $A B$, Santos JH, Van Houten $B$, Bonner JC: Vanadium-induced STAT-1 activation in lung myofibroblasts requires $\mathrm{H}_{2} \mathrm{O}_{2}$ and P38 MAP kinase. Free Radic Biol Med 2003, 35:845-855.

19. Walters DM, Antao-Menezes A, Ingram JL, Rice AB, Nyska A, Tani $Y$, Kleeberger SR, Bonner JC: Susceptibility of signal transducer and activator of transcription-1-deficient mice to pulmonary fibrogenesis. Am J Pathol 2005, 167(5):1221-1229.

20. Ingram JL, Antao-Menezes A, Turpin EA, Wallace DG, Mangum JB, Pluta LJ, Thomas RS, Bonner JC: Genomic analysis of human lung fibroblasts exposed to vanadium pentoxide to identify candidate genes for occupational bronchitis. Respir Res 2007, 25(8):34.

21. Ingram JL, Rice $A B$, Santos J, Van Houten B, Bonner JC: Vanadium-induced HB-EGF expression in human lung fibroblasts is oxidant dependent and requires MAP kinases. Am J Physiol 2003, 284:L774-L782.

22. Antao-Menezes A, Turpin EA, Bost PC, Ryman-Rasmussen JP, Bonner JC: STAT-1 Signaling in Human Lung Fibroblasts Is Induced by Vanadium Pentoxide through an IFN-\{beta\} Autocrine Loop. J Immunol 2008 180:4200-4207.

23. Stark JM, McDowell SA, Koenigsknecht V, Prows DR, Leikauf JE, Le Vine AM, Leikauf GD: Genetic susceptibility to respiratory syncytial virus infection in inbred mice. J Med Virol 2002, 67(1):92-100.

24. Moyron-Quiroz JE, Rangel-Moreno J, Kusser K, Hartson L, Sprague F, Goodrich S, Woodland DL, Lund FE, Randall TD: Role of inducible bronchus associated lymphoid tissue (iBALT) in respiratory immunity. Nat Med 2004, 10(9):927-934.

25. Cesta MF, Ryman-Rasmussen JP, Wallace DG, Masinde T, Hurlburt G, Taylor AJ, Bonner JC: Bacterial Lipopolysaccharide Enhances PDGF Signaling and Pulmonary Fibrosis in Rats Exposed to Carbon Nanotubes. Am J Respir Cell Mol Biol 2009, [Epub ahead of print].

26. Lambert AL, Trasti FS, Mangum JB, Everitt Jl: Effect of preexposure to ultrafine carbon black on respiratory syncytial virus infection in mice. Toxicol Sci 2003, 72(2):331-338.

27. Malley R, Vernacchio L, Devincenzo J, Ramilo O, Dennehy PH, Meissner HC, Gruber WC, Jafri HS, Sanchez PJ, Macdonald K, Montana JB, Thompson CM, Ambrosino DM: Enzyme-linked immunosorbent assay to assess respiratory syncytial virus concentration and correlate results with inflammatory mediators in tracheal secretions. Pediatr Infect Dis J 2000, 19(1):1-7.

28. Becnel D, You D, Erskin J, Dimina DM, Cormier SA: A role for airway remodeling during respiratory syncytial virus infection. Respir Res 2005, 6:122.

29. Colasurdo GN, Fullmer JJ, Elidemir O, Atkins C, Khan AM, Stark JM: Respiratory syncytial virus infection in a murine model of cystic fibrosis. J Med Virol 2006, 78(5):651-658.

30. Schwarze J, Hamelmann E, Bradley KL, Takeda K, Gelfand EW: Respiratory syncytial virus infection results in airway hyperresponsiveness and enhanced airway sensitization to allergen. J Clin Invest 1997, 100(1):226-233.

31. Ciencewicki J, Gowdy K, Krantz QT, Linak WP, Brighton L, Gilmour MI, Jaspers I: Diesel exhaust enhanced susceptibility to influenza infection is associated with decreased surfactant protein expression. Inhal Toxicol 2007, 19(14):1121-1133.
32. Ciencewicki J, Jaspers I: Air pollution and respiratory viral infection. Inhal Toxicol 2007, 19(14):1135-1146.

33. Khalil N, Greenberg AH: The role of TGF-beta in pulmonary fibrosis. Ciba Found Symp 1991, 157:194-207.

34. Shi-Wen X, Leask A, Abraham D: Regulation and function of connective tissue growth factor/CCN2 in tissue repair, scarring and fibrosis. Cytokine Growth Factor Rev 2008, 19(2):133-144.

35. Lambert AL, Mangum JB, DeLorme MP, Everitt JI: Ultrafine carbon black particles enhance respiratory syncytial virus-induced airway reactivity, pulmonary inflammation, and chemokine expression. Toxicol Sci 2003, 72(2):339-346.

36. Jaspers I, Ciencewicki JM, Zhang W, Brighton LE, Carson JL, Beck MA, Madden MC: Diesel exhaust enhances influenza virus infections in respiratory epithelial cells. Toxicol Sci 2005, 85(2):990-1002.

37. Vannella KM, Moore BB: Viruses as co-factors for the initiation or exacerbation of lung fibrosis. Fibrogenesis Tissue Repair 2008, 1(1):2

38. McMillan TR, Moore BB, Weinberg JB, Vannella KM, Fields WB, Christensen PJ, van Dyk LF, Toews GB: Exacerbation of established pulmonary fibrosis in a murine model by gammaherpesvirus. Am J Respir Crit Care Med 2008, 177(7):771-780

39. Neville LF, Mathiak G, Bagasra O: The immunobiology of interferongamma inducible protein $10 \mathrm{kD}$ (IP-10): a novel, pleiotrophic member of the C-X-C chemokine superfamily. Cytokine \& Growth Factor Rev 1997, 8:207-219.

40. Shingai M, Azuma M, Ebihara T, Sasai M, Funami K, Ayata M, Ogura H, Tsutsumi H, Matsumoto M, Seya T: Soluble $G$ protein of respiratory syncytial virus inhibits Toll-like receptor 3/4-mediated IFN-beta induction. Int Immunol 2008, 20(9):1169-80.

41. Shigeta S, Mori S, Kodama E, Kodama J, Takahashi K, Yamase T: Broad spectrum anti-RNA virus activities of titanium and vanadium substituted polyoxotungstates. Antiviral Res 2003, 58(3):265-71.

doi:10.1186/1465-9921-11-20

Cite this article as: Turpin et al:: Respiratory syncytial virus infection reduces lung inflammation and fibrosis in mice exposed to vanadium pentoxide. Respiratory Research 2010 11:20.

\section{Submit your next manuscript to BioMed Central and take full advantage of:}

- Convenient online submission

- Thorough peer review

- No space constraints or color figure charges

- Immediate publication on acceptance

- Inclusion in PubMed, CAS, Scopus and Google Scholar

- Research which is freely available for redistribution

Submit your manuscript at www.biomedcentral.com/submit
C Biomed Central 